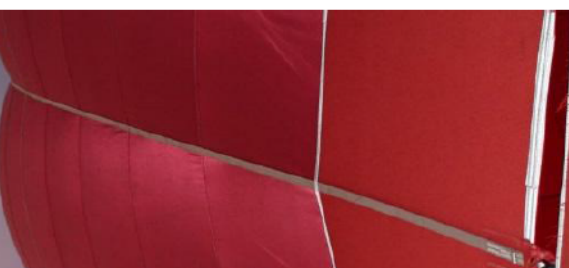

\title{
Kehittyvä käsityö haastaa opettajat, opettajankouluttajat ja tutkijat!
}

Käsityöoppiaine on perustamisensa 1866 jälkeen suurimman muutoksen myllerryksessä. Perusopetuksen opetussuunnitelma on uudistunut, käsityön oppimis- ja työympäristöjä kehitetään tekemisen pajojen, verstaiden ja designstudioiden näkökulmasta. Opettajankoulutus pyrkii uudistumaan, jotta oppiaineen kehittäminen keksimisprosesseja, teknologiaoppimista, yritteliäisyyttä ja innovaatiokompetensseja kehittäväksi toiminnalliseksi oppiaineeksi mahdollistuisi. Sanomalehdissä ja YLEn sivuilla käytiin vilkasta keskustelua siitä, pitäisikö palata vuoden 1998 perusopetuslakia edeltävään kahden erillisen käsityöoppiaineen aikaan ja kykeneekö opettajankoulutus enää tuottamaan päteviä opettajia kentälle.

Kehittyvä käsityö -teemanumero tarjoaa lukijalle nimensä mukaisesti käsityön pedagogista ja didaktista tutkimusta, jonka tuloksia voidaan soveltaa opetuksen kehittämiseen. Näin vastataan kentän opettajien ja opettajaopiskelijoiden tarpeeseen saada tieteellisiä tutkimustuloksia oman opetustyönsä lähtökohdaksi. Teemanumero esittelee tavoitteensa mukaisesti kattauksen käsityön opetukseen liittyviä näkökulmia: käsityön monimateriaalisen luonteen pohdintaa, käsityön tilasuunnittelukysymyksiä, keksintöprosessien tarkastelua, dokumentointia osana käsityön oppimisprosessia, kestävää kehitystä ja koneälyn hyödyntämistä.

Sinikka Pöllänen, Marja-Leena Rönkkö, Anssi Salonen, Tellervo Härkki ja Eila Lindfors tarkastelevat artikkelissaan monimateriaalisuuden käsitettä perusopetuksessa, pedagogisia esimerkkejä opetuksen toteutuksena sekä opiskeltavana sisältönä. Tutkijat korostavat kokonaisen käsityön merkitystä: opetuksessa otetaan huomioon oppilaan kiinnostuksen kohteet ja niihin sovellettavat tekstiilityön sekä teknisen työn työtavat yhdessä tai toisistaan erillisinä. Samalla nostetaan esille kehittyvien materiaaliteknologioiden tarjoamia mahdollisuuksia niin 3D-tulostuksen sekä lasertyöstöteknologian avulla.

Artikkelissaan Eila Lindfors, Juha Jaatinen, Miika Uljas ja Sara Wendelius esittelevät käsityön opetuksen tilasuunnittelua määrittäviä pedagogisia periaatteita, fyysisen oppimis- ja työympäristön reunaehtoja sekä käyttäjien osallistamista tilasuunnitteluprosessiin. Ensimmäinen käsityön tilasuunnitteluun keskittyvä suomenkielinen artikkeli tarjoaa 
tuloksia ja pohdintaa, joita voidaan hyödyntää koulujen uudisrakennus- ja peruskorjaushankkeissa.

Henna Lahti ja Sini Davies nostavat esille keksintöprosessien merkityksen osana käsityön opetuksen toteuttamista. Pitkäkestoista ideoiden kehittelyä ja kokeilua tarkastellaan kaavoitus- ja vaatetusprosessin aikana. Erityisen kiinnostavaksi tapaustutkimuksen tekee opetuskonteksti, jossa oppilaat suunnittelevat ja toteuttavat älyvaatteita. Älyvaateprojekti nostaa esille yhteiskehittelyn merkityksen. Toisaalta se tapahtuu vuorovaikutuksessa opettajan ja oppilaan välillä, mutta myös yhteisopetuksena kollegojen välillä. Tutkijat korostavat, että käsityön opetuksen tueksi tarvitaan keksimisprojektien malli, joka auttaisi myös digitaalisten elementtien kietomisessa osaksi vaatetuksen suunnittelua ja valmistusta.

Mia Porko-Hudd ja Barbro Sjöberg analysoivat kirjallisuuskatsauksessaan dokumentoinnin merkitystä ja tapoja käsityöprosessin aikana. Dokumentoinnin merkitys onkin nostettu Perusopetuksen opetussuunnitelman perusteissa (2014) keskeiseen asemaan. Suunnittelun ja kokeilujen dokumentointi konkretisoivat oppilaille käsityöprosessin vaiheet ja auttavat arvioinnissa. Oppilaita opastetaan käyttämään monipuolisesti tieto- ja viestintäteknologiaa käsityöprosessin dokumentoinnissa. Tässä tutkimuksessa kuvataan dokumentaatiovälineinä portfolio, luonnosteluvihko, päiväkirja ja erilaiset blogit sekä digitaalisina että käsin kosketeltavina ja samalla niiden tyypilliset käyttökohteet.

Niina Väänänen ja Sinikka Pöllänen tarkastelevat käsityön avulla edistettävää kestävän kehityksen mukaisten tietojen ja taitojen oppimista. Kestävä kehitys ja ilmastonmuutos hallitsevat merkittävästi kansallista ja kansainvälistä keskustelua ja käsityö oppiaineessa kestävyyskasvatus on Perusopetuksen opetussuunnitelman perusteiden (2014) mukaan sitoutunut toteuttamaan laaja-alaisesti kestävän tulevaisuuden periaatteita. Artikkeli on merkittävä avaus. Se korostaa käsityön opetuksen mahdollistamaa kestävän kehityksen periaatteiden huomioon ottamista koko käsityöprosessin ajan arvoja ja asenteita muokkaavana, elinkaaren hahmottavana ja laajana kulttuurisena ymmärryksenä.

Tekoälyä pidetään keskeisenä tulevaisuuden teknologiana, ja Henriikka Vartiaisen, Matti Tedren, Ilkka Jormanaisen, Juho Kahilan, Teemu Valtosen ja Tapani Toivosen artikkeli tarkastelee datatoimijuutta sekä datalähtöistä design-ajattelua koneoppimisen muovaamassa maailmassa sekä avaa tekoälyn käsitettä osana perusopetuksen toteutusta. Tutkijat esittelevät koneoppimisen hyötyä ja riskejä sekä tekoälyn hyödyntämistä osana käsityön ja teknologiakasvatuksen tulevaisuudesta käytävää tieteellistä ja julkista keskustelua. Keskustelussa nostetaan esille datayhteiskunnassa tarvittavat kansalais- ja työelämätaidot.

Toivomme lukijoille ajatuksia herättäviä, tutkimukseen ja opetuksen sekä oppimisympäristöjen kehittämiseen kannustavia lukuhetkiä!

\section{Eila Lindfors ja Marja-Leena Rönkkä}

Turun yliopisto, Kasvatustieteiden tiedekunta, Opettajankoulutuslaitos, Rauman kampus 